\title{
AKTIVITAS ANTIOKSIDAN MINUMAN FUNGSIONAL DAUN KATUK-ROSELLA (Sauropus androgynous (L) Merr.-Hibiscus sabdariffa Linn) DENGAN PENAMBAHAN EKSTRAK JAHE (Zingiber officinale Rosc.)
}

\author{
(Antioxidant Activity of Functional Drinks Katuk-Rosella ((Sauropus \\ androgynous (L) Merr.-Hibiscus sabdariffa Linn)with Addition of Ginger \\ Extract (Zingiber officinale Rosc.))
}

\author{
Naradhita Dewi Marganingsih, Akhmad Mustofa, Yannie Asrie Widanti \\ Fakultas Teknologi dan Industri Pangan Universitas Slamet Riyadi Surakarta, \\ Jl. Sumpah Pemuda 18 Joglo Kadipiro Surakarta 57136 \\ Email: naradhitadewig6@gmail.com
}

\begin{abstract}
ABSTRAK
Antioksidan merupakan senyawa yang penting untuk menjaga kesehatan tubuh karena fungsinya sebagai penangkap radikal bebas yang terbentuk dalam tubuh. Daun katuk, rosella, dan jahe termasuk tanaman yang kaya antioksidan.Salah satu usaha untuk memperoleh sumber antioksidan secara praktis adalah dengan mengolah daun katuk, bunga rosella dan jahe menjadi minuman fungsional.Penelitian ini bertujuan untuk menentukan formula minuman fungsional katuk-rosella dan penambahan ekstrak dari berbagai jenis jahe yang memiliki aktivitas antioksidan tinggi dan disukai konsumen.Penelitian dilakukan dengan Rancangan Acak Lengkap (RAL) faktorial yang terdiri dari 2 faktor.Faktor pertama dengan perbandingan daun katuk dan rosella (90:10, 80:20, 70:30) sedangkan faktor yang kedua yaitu variasi jenis jahe (jahe emprit, jahe gajah dan jahe merah). Hasil penelitian menunjukkan bahwa kombinasi perlakuan konsentrasi daun katuk : rosella 80:20 dengan ekstrak jahe merah 8\% merupakan perlakuan terbaik didasarkan pada aktivitas antioksidan dan uji organoleptik terbaik yang terdapat pada minuman. Pada perlakuan ini dihasilkan $\mathrm{pH}$ 2,83, padatan terlarut 15,46\%, aktivitas antioksidan DPPH 54,65\%, total fenol o,98 mg GAE/10oml, vitamin C 68,82 mg/10oml, serta uji organoleptik terhadap flavor jahe 2,13, flavor katuk 1,86, rasa asam 2,73, warna 3,65 dan kesukaan keseluruhan 2,20.
\end{abstract}

Kata kunci:antioksidan, minuman fungsional, daun katuk, rosella, jahe

\begin{abstract}
Antioxidants are important compounds for maintain a healthy body because of its function as a free radical scavenger that are formed in the body. Katuk leaf, rosella, and ginger are plants that have many antioxidants. One of effort to obtain a source of antioxidants in practice way was processing katuk leaf, rosella and ginger into functional drinks. This aims of this research was to determine the formula of katuk-rosella functional drinks and addition of extracts of various types of ginger extract which had high antioxidant activity and favored by consumers. The research was conducted using completely randomized design (CRD) which consist of 2 factors. The first factor was the comparison of katuk leaf and rosella (90:10, 80:20, 70:30) while the second factor was variation of ginger type (emprit ginger, gajah ginger and red ginger). The results showed that treatment with katuk leaf: rosella 80:20 and 8\% of red ginger extract was the best treatment based on the antioxidant's activity and the best organoleptic test. This treatment resulted $p \mathrm{H}_{2} .83$, soluble solid $15.46 \%, \mathrm{DPPH}$ of antioxidant activity $54.65 \%$, total phenol $0.98 \mathrm{mg} \mathrm{GAE} / 100 \mathrm{ml}$, vitamin C $68,82 \mathrm{mg} / 100 \mathrm{ml}$, organoleptic test to flavor of ginger 2.13, flavor of katuk 1.86, sour flavor 2.73, colour 3.65 and overall favorite 2.20.
\end{abstract}

Keywords: antioxidants, functional drinks, katuk, rosella, ginger

Jurnal Teknologi dan Industri Pangan 3 (2): 144-151 


\section{PENDAHULUAN}

Antioksidan telah dikenal oleh masyarakat sebagai zat aktif yangbermanfaat bagi kesehatan tubuh manusia. Fungsi antioksidan untuk mengatasi atau menetralisir radikal bebas agar dapat menghambat proses penuaan sertadapat mencegah terjadinya kerusakan tubuh dari timbulnya penyakit degeneratif (Kosasihet al., 2006).

Sumber-sumber antioksidan dapat berupa antioksidan alami dan antioksidan sintetik, namun penggunaan sumber antioksidan sintetik mulai dibatasi karena bersifat karsinogenik.Oleh karena itu, industri pangan dan obat-obatan mulai beralih mengembangkan antioksidan alami.Kebanyakan sumber antioksidan alami adalah tumbuhan dan umumnya merupakan senyawa fenolik yang tersebar di seluruh bagian tumbuhan baik di kayu, biji, daun, buah, akar, bunga maupun serbuk sari (Sarastaniet al., 2002).Daun katuk merupakan salah satu jenis sayuran yang memiliki kandungan antioksidan. Tumbuhan ini banyak terdapat di daerah Asia Tenggara.Daun katuk memiliki banyak fungsi kesehatan bagi tubuh jika dikonsumsi, sehingga disebut sebagai tanaman obat (Santoso, et al. 2008).Di dalam daun katuk terkandung beberapa senyawa kimia antara lain alkaloid papaverin, protein, lemak, vitamin, mineral, saponin, flavonoid dan tanin.Kandungan flavonoid didalam daun katuk inilah yang membuat daun katuk memiliki fungsi sebagai antioksidan alami, karena flavonoid memiliki kemampuan untuk merubah atau mereduksi radikal bebas dan juga sebagai anti radikal bebas (Giorgio, 2000).

Selain daun katuk, salah satu bahan yang memiliki kandungan antioksidan adalah bunga rosella.Bunga rosella memiliki kandungan antioksidan tinggi yang mampu menangkap radikal bebas penyebab kanker (Mangan, 2009). Bunga rosella merupakan salah satu jenis tanaman yang banyak digunakan sebagai minuman yang mengandung asam sitrat dan malat sehingga mempunyai rasa mild asam manis yang segar dan khas dengan warna merah yang alami.

Jahe merupakan jenis tanaman rimpang yang memiliki rasa pedas karena mengandung senyawa keton yang bernama zingeron.Pada umumnya, jahe banyak dimanfaatkan sebagai bumbu masakan dan obat, seperti obat masuk angin, sakit kepala dan menambah nafsu makan. Jahe memiliki kandungan aktif yaitu oleoresin yang bersifat sebagai antioksidan dan berfungsi sebagai aroma dan pembawa rasa.

Pangan fungsional merupakan suatu makanan atau minuman yang mempunyai karakteristik warna, tekstur dan cita rasa yang dapat diterima konsumen dan bermanfaat bagi tubuh. Menurut Badan POM (2001), pangan fungsional adalah pangan yang secara alami maupun telah melalui proses mengandung satu atau lebih senyawa yang berdasarkan kajiankajian ilmiah dianggap mempunyai fungsifungsi fisiologis tertentu yang bermanfaat bagi kesehatan.

Bahan pangan terutama dalam bentuk segar seperti daun katuk segar dan jahe segar memiliki masa simpan yang cukup singkat, sehingga pemanfaatannya kurang optimal. Untuk mengoptimalkan pemanfaatannya, bahan dapat diolahmenjadi minuman fungsional sebagai produk yang memiliki sumber gizi dan meningkatkan harga jualnya.Pada jaman modern ini, masyarakat mulai memperhatikan kesehatan tubuh dengan mengkonsumsi makanan dan minuman yang bergizi namun disajikan secara praktis, tahan lama, dan mudah dibawa.Oleh karena itu, pembuatan minuman fungsional dengan bahan dasar daun katuk dan bunga rosella dengan penambahan jahe dapat menjadi minuman fungsional sebagai sumber gizi terutama sumber antioksidan. Penelitian ini bertujuan untuk mengetahui aktivitas antioksidan dan tingkat kesukaan pada minuman fungsional katuk-rosella dengan penambahan ekstrak dari berbagai jenis jahe dan menentukan formula minuman fungsional katuk-rosella dan penambahan ekstrak dari berbagai jenis jahe yang memiliki aktivitas antioksidan tinggi dan disukai konsumen.

\section{METODE PENELITIAN \\ Alat}

Alat yang digunakan untuk penelitian antara lain tabung reaksi (Pyrex), tabung erlenmeyer (pyrex), pH meter (Oakion), 
refraktometer (Atago) dan Spektrofotometer (Thermo Scientific).

\section{Bahan}

Bahan-bahan yang digunakan antara lain daun katuk, jahe merah, jahe emprit, jahe gajah dan kelopak bunga rosella yang diperoleh di Pasar Gede Solo, sedangkan bahan untuk analisis kimia antara lain amilum $1 \%$, Iodin o,o1 $\mathrm{N}, \mathrm{DPPH}$ o, $1 \mathrm{mM}$, Folin Ciocalteau $50 \%, \mathrm{Na}_{2} \mathrm{CO}_{3}$ $5 \%$ dan etanol $95 \%$.

\section{Rancangan Percobaan}

Penelitian ini menggunakan Rancangan Acak Lengkap (RAL) faktorial, dengan dua faktor yaitu faktor pertama rasio perbandingan ekstrak daun katuk dengan ekstrak bunga rosella (90:10; 80:20 dan 70:30) dan faktor kedua jenis jahe (jahe emprit, jahe gajah dan jahe merah).

Rancangan tersebut akan memperoleh 9 kombinasi perlakuan,masing-masing perlakuan diulang sebanyak dua kali. Data yang diperoleh dianalisis dengan uji sidik ragam pada jenjang nyata 0,05 . Jika adabeda nyata dilanjutkan uji Tukey untuk mengetahui beda nyata antar perlakuan pada tingkat signifikansi $5 \%$.

\section{TAHAPAN PENELITIAN}

\section{Pembuatan Ekstrak Daun Katuk}

Daun katuk yang dipilih adalah daun katuk yang baik.Kemudian daun katuk dicuci hingga bersih dan ditiriskan.Daun katuk yang sudah ditiriskan lalu direbus dengan suhu $90^{\circ} \mathrm{C}$ selama 10 menit dan ditiriskan. Setelah itu daun katuk dihaluskan menggunakan mesin blender dengan rasio katuk : air (1:5) kemudian disaring dengan kain saring dan didapatkan ekstrak daun katuk (Lumbangaol et al, 2016).

\section{Pembuatan Ekstrak Jahe}

Disiapkan berbagai jenis jahe yaitu, jahe gajah, jahe emprit, dan jahe merah. Dipilih jahe yang terbaik pada masing-masing jenis jahe tersebut dan dikupas. Jahe yang telah dikupas dicuci hingga bersih dilanjutkan dengan dihaluskan dengan perbandingan jahe : air (1:2). Kemudian jahe yang telah dihaluskan disaring dan diendapkan selama 1 jam.Jahe yang diendapkan lalu disaring dan dihasilkan ekstrak jahe dari masing-masing jenis jahe (Yazakka dan Susanto, 2015).

\section{Pembuatan Ekstrak Bunga Rosella}

Bunga rosella kering disortir kemudian dihaluskan dengan mesin blender selama 1020 detik. Bunga rosella yang sudah dihaluskan tersebut diayak lalu diseduh dengan air 1000 $\mathrm{ml}$. Setelah itu, dipanaskan dengan suhu $100^{\circ} \mathrm{C}$ selama 10 menit dan dihasilkan ekstrak bunga rosella (Hastuti, 2012).

\section{Cara Pengumpulan Data}

Analisisyang digunakan dalam penelitian ini yaitu analisis kimia, fisika dan uji organoleptik. Analisis kimia dan fisika terdiri dari analisis $\mathrm{pH}$ menggunakan $\mathrm{pH}$ meter (Maitimu et al.,2012), analisis total fenol dengan metode Folin-Ciocalteu (Strycharz danShetty, 2002), analisis aktivitas antioksidan dengan metode DPPH (Yen dan Chen, 1995), vitamin C dengan metode titrasi iodium (Sudarmadji et al., 1984), analisis padatan terlarut menggunakan alat refraktometer Abbe (Pomeranz dan Meloan, 1980) dan uji organoleptik dengan metode scoring test (Kartika et al., 1988) meliputi: warna, rasa asam, flavor jahe, flavor katuk dan kesukaan keseluruhan. 
HASIL DAN PEMBAHASAN

\section{Analisis Kimia}

Tabel 1.Rangkuman Hasil Analisis Kimia dan Fisika Minuman Fungsional Katuk-Rosella dan Ekstrak Jahe

\begin{tabular}{|c|c|c|c|c|c|c|}
\hline \multirow{2}{*}{$\begin{array}{l}\text { Ekstrak } \\
\text { Jahe } 8 \%\end{array}$} & \multirow{2}{*}{$\begin{array}{l}\text { Perbandingan } \\
\text { Katuk : Rosella }\end{array}$} & \multicolumn{5}{|c|}{ Analisis Kimiawi } \\
\hline & & $\begin{array}{c}\text { Derajat } \\
\text { Keasaman }\end{array}$ & $\begin{array}{l}\text { Padatan } \\
\text { Terlarut }\end{array}$ & $\begin{array}{c}\text { Aktivitas } \\
\text { Antioksidan } \\
\text { DPPH(\%) }\end{array}$ & $\begin{array}{l}\text { Total Fenol } \\
(\mathrm{mg} \mathrm{GAE} / 100 \\
\mathrm{ml})\end{array}$ & $\begin{array}{l}\text { Vitamin C } \\
(\mathrm{mg} / 100 \mathrm{ml})\end{array}$ \\
\hline $\begin{array}{l}\text { Jahe } \\
\text { Emprit }\end{array}$ & $\begin{array}{l}90: 10 \\
80: 20 \\
70: 30\end{array}$ & $\begin{array}{l}3.13^{\mathrm{c}} \\
2.73^{\mathrm{ab}} \\
2.63^{\mathrm{a}}\end{array}$ & $\begin{array}{l}15.10^{\mathrm{ab}} \\
15.43^{\mathrm{ab}} \\
16.33^{\mathrm{b}}\end{array}$ & $\begin{array}{l}34.91^{\mathrm{c}} \\
45 \cdot 99^{\mathrm{e}} \\
62.08^{\mathrm{g}}\end{array}$ & $\begin{array}{c}.29^{\mathrm{a}} \\
.95^{\mathrm{b}} \\
2.09^{\mathrm{d}}\end{array}$ & $\begin{array}{c}56.07^{\mathrm{ab}} \\
61.17^{\mathrm{ab}} \\
68.82^{\mathrm{ab}}\end{array}$ \\
\hline $\begin{array}{l}\text { Jahe } \\
\text { Gajah }\end{array}$ & $\begin{array}{l}90: 10 \\
80: 20 \\
70: 30\end{array}$ & $\begin{array}{l}3.23^{\mathrm{cd}} \\
2.73^{\mathrm{ab}} \\
2.66^{\mathrm{ab}}\end{array}$ & $\begin{array}{c}14.60^{\mathrm{a}} \\
15 \cdot 13^{\mathrm{ab}} \\
15 \cdot 76^{\mathrm{ab}}\end{array}$ & $\begin{array}{l}19.79^{\mathrm{a}} \\
40.75^{\mathrm{d}} \\
51.18^{\mathrm{f}}\end{array}$ & $\begin{array}{l}.26^{\mathrm{a}} \\
.67^{\mathrm{b}} \\
1.52^{\mathrm{d}}\end{array}$ & $\begin{array}{c}43 \cdot 33^{\mathrm{a}} \\
56.07^{\mathrm{ab}} \\
63.72^{\mathrm{ab}}\end{array}$ \\
\hline $\begin{array}{l}\text { Jahe } \\
\text { Merah }\end{array}$ & $\begin{array}{l}90: 10 \\
80: 20 \\
70: 30\end{array}$ & $\begin{array}{l}3.33^{\mathrm{d}} \\
2.83^{\mathrm{b}} \\
2.63^{\mathrm{a}}\end{array}$ & $\begin{array}{c}14.66^{\mathrm{a}} \\
15.46^{\mathrm{ab}} \\
16.03^{\mathrm{b}}\end{array}$ & $\begin{array}{l}27 \cdot 34^{\mathrm{b}} \\
54.65^{\mathrm{f}} \\
73 \cdot 52^{\mathrm{h}}\end{array}$ & $\begin{array}{l}1.39^{\mathrm{c}} \\
.98^{\mathrm{b}} \\
2.21^{\mathrm{c}}\end{array}$ & $\begin{array}{l}63.72^{\mathrm{ab}} \\
68.82^{\mathrm{b}} \\
79.02^{\mathrm{b}}\end{array}$ \\
\hline
\end{tabular}

Keterangan: Rerata yang diikuti huruf yang berbeda pada kolom yang sama menunjukkan beda nyata pada uji Tukey taraf signifikan $5 \%$

\section{Derajat Keasaman (pH)}

Hasil analisis sidik ragam menunjukkan bahwa derajat keasaman $(\mathrm{pH})$ minuman fungsional katuk-rosella dengan penambahan jahe pada perlakuan penambahan ekstrak katuk : rosella, kadar ekstrak jahe dan kombinasi perlakuannya menunjukkan hasil berbeda nyata. Derajat keasaman $(\mathrm{pH})$ tertinggi ditunjukkan pada minuman fungsional dengan perlakuan penambahan ekstrak katuk : rosella yaitu 90:10 dan ekstrak jahe merah $8 \%$ yaitu 3.33. Derajat keasaman $(\mathrm{pH})$ terendah yaitu 2.63 pada perlakuan pemberian ekstrak jahe emprit 8\% dan ekstrak jahe merah 8\% dengan perlakuan penambahan ekstrak katuk : rosella 70:30. Hal ini dikarenakan di dalam bunga rosella terdapat senyawa organik.Arelanoet al. (2004) menyatakan bahwa dalam rosella terkandung asam hibiscus dan 6-metil esternya, asam protokatekin yang merupakan senyawa polifenol asam askorbat, malat dan hibiskat.Hal ini menunjukkan bahwa rosella memberikan sumber rasa asam yang menjadikan minuman menjadi asam.Semakin banyak bunga rosella maka pH minuman semakin rendah, dan jahe merah memiliki pH lebih tinggi sedangkan jahe emprit memiliki pH lebih rendah.

\section{Total Padatan Terlarut}

Padatan terlarut tertinggi ditunjukkan pada minuman fungsional dengan perlakuan penambahan ekstrak katuk : rosella 70:30 dan ekstrak jahe emprit 8\% yaitu sebesar $16.33 \%$. Padatan terlarut terendah pada perlakuan penambahan ekstrak katuk : rosella 90:10 dan pemberian ekstrak jahe gajah $8 \%$ yaitu sebesar $14.60 \%$. Hasil data menunjukkan semakin banyaknya bunga rosella maka padatan terlarutnya semakin tinggi. Kelopak bunga rosella mengandung pektin, dan pektin merupakan salah satu dari kandungan padatan terlarut. Jahe juga memberikan pengaruh terhadap padatan terlarut pada minuman, karena pada jahe terkandung pati dimana pati akan mengalami degradasi pati membentuk gula-gula sederhana. Hasil sidik ragam menunjukkan padatan terlarut pada minuman fungsional katuk-rosella dengan penambahan ekstrak jahe pada perlakuan penambahan kadar ekstrak jahe menunjukkan hasil berbeda tidak nyata, sedangkan pada perlakuan penambahan ekstrak katuk : rosella dan kombinasi perlakuannya menunjukkan hasil berbeda nyata.

\section{Aktivitas Antioksidan Metode DPPH}

Hasil sidik ragam menunjukkan aktivitas 
antioksidan pada minuman fungsional katukrosella dengan penambahan ekstrak jahe pada perlakuan penambahan ekstrak katuk : rosella, kadar ekstrak jahe dan kombinasi perlakuannya menunjukkan hasil berbeda nyata. Aktivitas antioksidan tertinggi ditunjukkan pada minuman fungsional dengan perlakuan penambahan ekstrak katuk : rosella 70:30 dan ekstrak jahe merah $8 \%$ yaitu sebesar $73.52 \%$. Aktivitas antioksidan terendah pada perlakuan penambahan ekstrak katuk : rosella sebesar 90:10 dengan pemberian ekstrak jahe gajah 8\% yaitu sebesar $19.79 \%$. Bunga rosella dan daun katuk memiliki senyawa antioksidan alami tetapi pada penelitian ini aktivitas antioksidan pada bunga rosella lebih tinggi dibandingkan daun katuk karena proses perebusan pada daun katuk, dan aktivitas antioksidan jahe merah lebih tinggi dibandingkan jahe emprit dan jahe gajah. Hernani dan Hayani (2001) menyatakan bahwa kandungan minyak atsiri dan kelarutan menentukan besarnya antioksidan dan total fenol yang terkandung dalam jahe. Kandungan minyak atsiri jahe merah $(3,9 \%)$ dan ekstrak yang larut dalam alkohol (9,93\%) lebih tinggi dari jahe emprit yaitu 3,5\% dan 7,29\% serta jahe gajah 2,5\% dan 5,81\% (Hernani dan Hayani,2001).

\section{Total Fenol}

Menurut Malangngi et al (2012), uji total fenol bertujuan untuk melihat seberapa besar kandungan bahan aktif yang terdapat pada suatu bahan makanan. Hasil sidik ragam menunjukkan total fenol pada minuman fungsional katuk-rosella dengan penambahan ekstrak jahe pada perlakuan penambahan ekstrak katuk : rosella, kadar ekstrak jahe dan kombinasi perlakuannya menunjukkan hasil berbeda nyata. Total fenol tertinggi ditunjukkan pada minuman fungsional tersebut dengan perlakuan penambahan ekstrak katuk : rosella 70:30 dan ekstrak jahe merah 8\% yaitu sebesar $2.21 \mathrm{mg}$ GAE/10o ml. Total fenol terendah pada perlakuan penambahan ekstrak katuk : rosella 90:10 dengan pemberian ekstrak jahe gajah 8\% yaitu sebesar $0.26 \mathrm{mg}$ GAE/100 ml. Semakin banyak bunga rosella yang ditambahkan, maka nilai total fenol akan semakin tinggi. Menurut Hastuti (2012) total fenol pada bunga rosella kering yang dipanaskan selama 10 menit sebesar $6,491 \mathrm{mg} / \mathrm{g}$. Pada penelitian ini jahe merah memiliki total fenol tertinggi dibandingkan jahe emprit dan jahe gajah, hal ini dikarenakan pada jahe merah memiliki kandungan fenol yang paling tinggi dibandingkan dengan jahe emprit dan jahe gajah (Rehman et al., 2011).

\section{Vitamin C}

Menurut Winarno (2004), Vitamin C mampu menangkap berbagai radikal bebas, sehingga vitamin $\mathrm{C}$ termasuk golongan antioksidan. Semakin tinggi vitamin $C$ pada bahan maka aktivitas antioksidannya juga tinggi. Hasil sidik ragam menunjukkan kadar vitamin $C$ pada minuman fungsional katukrosella dengan penambahan ekstrak jahe pada perlakuan pemberian ekstrak katuk : rosella, kadar ekstrak jahe dan kombinasi perlakuannya menunjukkan hasil berbeda nyata. Kadar vitamin $C$ tertinggi ditunjukkan pada minuman fungsional dengan perlakuan penambahan ekstrak katuk:rosella 70:30 dan ekstrak jahe merah $8 \%$ yaitu sebesar $79.02 \mathrm{mg} / 100 \mathrm{ml}$. Kadar vitamin $C$ terendah pada perlakuan penambahan ekstrak katuk:rosella 90:10 dan ekstrak jahe gajah $8 \%$ yaitu sebesar $43.33 \mathrm{mg} / 100$ $\mathrm{ml}$. Pada hasil penelitian menunjukkan bahwa penambahan bunga rosella mempengaruhi besarnya kandungan vitamin $C$. Menurut Mukaromah (2010) kandungan vitamin C pada bunga rosella segar sebesar $102 \mathrm{mg} / 100 g$. Menurut Departemen Kesehatan RI (1981) daun katuk segar juga mengandung vitamin $C$ sebesar 239 mg/10og, karena pada proses pembuatan daun katuk direbus, sehingga kandungan vitamin $C$ pada daun katuk berkurang. Jahe juga mengandung vitamin $C$ sebesar $4 \mathrm{mg}$ (Departemen Kesehatan RI (1972), sehingga akan mempengaruhi kandungan vitamin $C$ pada minuman. 


\section{Uji Organoleptik}

Tabel 2.Rangkuman Hasil Analisis Uji Organoleptik Fungsional Katuk-Rosella dan Ekstrak Jahe

\begin{tabular}{c|c|c|c|c|c|c}
\hline \multirow{2}{*}{$\begin{array}{c}\text { Ekstrak Jahe } \\
8 \%\end{array}$} & $\begin{array}{c}\text { Perbandingan } \\
\text { Katuk }:\end{array}$ & \multicolumn{5}{|c|}{ Uji Organoleptik } \\
\cline { 3 - 7 } & Rosella & $\begin{array}{c}\text { Flavor } \\
\text { Jahe }\end{array}$ & $\begin{array}{c}\text { Flavor } \\
\text { Katuk }\end{array}$ & $\begin{array}{c}\text { Rasa } \\
\text { Asam }\end{array}$ & Warna & $\begin{array}{c}\text { Kesukaan } \\
\text { keseluruhan }\end{array}$ \\
\hline Jahe Emprit & $90: 10$ & $3.26^{\mathrm{c}}$ & $3.06^{\mathrm{b}}$ & $1.73^{\mathrm{a}}$ & $1.77^{\mathrm{a}}$ & $2.60^{\mathrm{a}}$ \\
& $80: 20$ & $2.60^{\mathrm{bc}}$ & $2.60^{\mathrm{b}}$ & $2.80^{\mathrm{b}}$ & $2.41^{\mathrm{ab}}$ & $2.33^{\mathrm{a}}$ \\
& $70: 30$ & $2.26^{\mathrm{ab}}$ & $1.33^{\mathrm{a}}$ & $3.60^{\mathrm{cd}}$ & $3.43^{\mathrm{cd}}$ & $2.00^{\mathrm{a}}$ \\
\hline Jahe Gajah & $90: 10$ & $2.33^{\mathrm{ab}}$ & $3.20^{\mathrm{b}}$ & $1.93^{\mathrm{a}}$ & $1.82^{\mathrm{a}}$ & $2.46^{\mathrm{a}}$ \\
& $80: 20$ & $2.00^{\mathrm{ab}}$ & $2.66^{\mathrm{b}}$ & $3.06^{\mathrm{bc}}$ & $2.87^{\mathrm{bc}}$ & $2.06^{\mathrm{a}}$ \\
& $70: 30$ & $1.73^{\mathrm{a}}$ & $1.46^{\mathrm{a}}$ & $3.73^{\mathrm{d}}$ & $3.65^{\mathrm{d}}$ & $1.73^{\mathrm{a}}$ \\
\hline Jahe Merah & $90: 10$ & $2.53^{\mathrm{abc}}$ & $3.13^{\mathrm{b}}$ & $1.73^{\mathrm{a}}$ & $1.90^{\mathrm{a}}$ & $2.33^{\mathrm{a}}$ \\
& $80: 20$ & $2.13^{\mathrm{ab}}$ & $1.86^{\mathrm{a}}$ & $2.73^{\mathrm{b}}$ & $3.65^{\mathrm{d}}$ & $2.20^{\mathrm{a}}$ \\
& $70: 30$ & $1.86^{\mathrm{ab}}$ & $1.33^{\mathrm{a}}$ & $3.53^{\mathrm{c}}$ & $3.67^{\mathrm{d}}$ & $1.67^{\mathrm{a}}$ \\
\hline
\end{tabular}

Keterangan :

Flavor Jahe $\quad$ : Angka tertinggi menunjukkan flavor jahe semakin terasa

Flavor Katuk : : : Angka tertinggi menunjukkan flavor katuk semakin terasa langu

Rasa Asam : : Angka tertinggi menunjukkan rasa minuman semakin asam

Warna : Angka tertinggi menunjukkan warna merah tua

Kesukaan keseluruhan : Angka tertinggi menunjukkan minuman semakin disukai

\section{Flavor Jahe}

Menurut Kartika et al. (1988), indikasi cita rasa atau flavor dari suatu produk ditimbulkan oleh kesan dari kedua indera manusia yaitu pembau dan perasa. Hasil analisis sidik ragam menunjukkan bahwa flavor jahe pada minuman fungsional katuk-rosella dengan penambahan jahe pada perlakuan pemberian katuk : rosella, penambahan ekstrak jahe dan kombinasi perlakuannya menunjukkan hasil berbeda nyata. Hasil penelitian menunjukkan bahwa pada perlakuan pemberian katuk : rosella 90:10 dan penambahan ekstrak jahe emprit $8 \%$ menunjukkan flavor jahe lebih terasa yaitu sebesar 3.26 dapatdiketahui bahwa jahe emprit memiliki flavor yang lebih terasa.

\section{Flavor Katuk}

Indera pengecap (lidah) dan indera penciuman (hidung) berperan penting dalam menentukan flavor pada suatu produk. Hasil analisis sidik ragam menunjukkan bahwa flavor katuk pada minuman fungsional katuk-rosella, penambahan ekstrak jahe dan kombinasi perlakuannya menunjukkan hasil berbeda nyata. Hasil penelitian bahwa pada perlakuan katuk : rosella 90:10 dan penambahan ekstrak jahe gajah 8\% memberikan flavor katuk lebih terasa yaitu sebesar 3.20.

\section{Rasa Asam}

Menurut Winarno (2004) indera pengecap pada lidah manusia merupakan parameter mutu dalam menentukan rasa. Hasil analisis sidik ragam menunjukkan bahwa rasa asam pada minuman fungsional katuk-rosella dengan penambahan jahe untuk perlakuan penambahan ekstrak jahe menunjukkan hasil berbeda tidak nyata, sedangkan untuk perlakuan penambahan katuk : rosella dan kombinasi perlakuannya menunjukkan hasil berbeda nyata. Hasil penelitian menunjukan bahwa pada perlakuan pemberian katuk : rosella 70:30 dan penambahan ekstrak jahe gajah $8 \%$ menunjukkan rasa asam yang tinggi pada minuman dengan $\mathrm{pH}$ sebesar 3.73, karena semakin banyak rosella yang ditambahkan maka semakin asam, dan jahe emprit dan jahe merah memiliki rasa jahe yang kuat sehingga sedikit menutupi rasa asam pada rosella, sedangkan pada jahe gajah memiliki rasa jahe yang tidak kuat sehingga rasa asam pada rosella lebih kuat. 


\section{Warna}

Warnamerupakan parameter atribut mutu yang ditangkap oleh indramata begitu kita melihat, sehingga sangat penting keberadaanya dalam menentukan penerimaan konsumen (Kartika et al., 1988). Hasil penelitian pada perlakuan katuk : rosella 70:30 dan ekstrak jahe merah $8 \%$ memiliki warna yang paling merah. Semakin banyak rosella yang ditambahkan, maka warna pada minuman katuk-rosella dan jahe semakin merah. Menurut Supiyanti et al. (2010), peningkatan kepekatan warna pada setiap penambahan konsentrasi ekstrak rosella diduga karena terjadi peningkatan kadarantosianin dan penurunan $\mathrm{pH}$ mempengaruhi warna pada setiap produk. Ekstrak jahe merah memberi warna yang paling merah karena pada jahe merah terdapat senyawa polifenol oksidase dan terjadi reaksi yang disebut reaksi pencoklatan.

\section{Kesukaan Keseluruhan}

Kesukaan keseluruhan meerupakan kesukaan panelis terhadap suatu produk secara umum dari sifat-sifat uji organoleptik. Hasil analisis sidik ragam menunjukkan bahwa kesukaan keseluruhan pada minuman fungsional katuk-rosella dengan penambahan jahe pada perlakuan pemberian katuk : rosella menunjukkan hasil berbeda nyata, sedangkan untuk perlakuan jenis jahe dan kombinasi perlakuannya menunjukkan hasil berbeda tidak nyata. Hasil penelitian pada perlakuan pemberian katukmaitimu : rosella 90:10 dan penambahan ekstrak jahe emprit 8\% lebih banyak disukai yaitu sebesar 2.6o. Berdasarkan hasil uji kesukaan pada minuman katuk-rosella dan jahe ini, menunjukkan hasil berbeda tidak nyata, yang artinya bahwa kesukaan panelis terhadap minuman fungsional ini hampir sama yaitu sedikit suka.

\section{KESIMPULAN}

Perbedaan konsentrasi dan jenis jahe masing-masing perlakuan berpengaruh terhadap aktivitas antioksidan minuman fungsional katuk-rosella dan jahe. Semakin besar konsentrasi rosella maka aktivitas antioksidan semakin meningkat, dan penggunaan jahe merah meningkatkan aktivitas antioksidan.
Minuman katuk-rosella dengan perlakuan katuk : rosella 8o:20 dan ekstrak jahe merah 8\% merupakan formulasi minuman fungsional yang terbaik karena memiliki sifat fungsional yang diharapkan yaitu aktivitas antioksidan $54,65 \%$, total fenol o,98 mg GAE/10o ml, vitamin c 68,82 $\mathrm{mg} / 100 \mathrm{ml}, \mathrm{pH}$ 2,83 dan padatan terlarut 15,46, flavor jahe terasa $(2,13)$, flavor katuk tidak terasa $(1,86)$, sedikit terasa asam $(2,73)$, warna merah cerah $(3,65)$.

\section{DAFTAR PUSTAKA}

Arelano, H.A., Romero, S.F., and Tortoriello, 2004. Effectinencess and Tolerability of a Standardizied Extract from Hibiscus sabdariffa in Patiens With Mild to Moderate Hypertention: a Controlled and Randomized Clinical Triad. Phytomedicine.11(5): 375-382.

Badan Pengawasan Obat dan Makanan, 2001. Kajian Proses Standarisasi Produk Pangan Fungsional di Badan Pengawas Obat dan Makanan.Lokakarya Kajian Penyusunan Standar Pangan Fungsional. Jakarta: Badan Pengawasan Obat dan Makanan.

Departemen Kesehatan RI, 1981. Composition List of Foodstuff. Jakarta : Bharata.

Giorgio, P., 200o. Flavonoid an Antioxidant. JournalNational Product. 63:1035-1045. Hastuti, N.D., 2012. Pembuatan Minuman Fungsional dari Madu dan Ekstrak Rosella (Hibiscus sabdariffa Linn.). Jurnal Teknologi Pangan. 3(1): 29-63.

Hernani dan Hayani, E., 2001. Identification of Chemical Components on Red Ginger (Zingiber officinale var. Rubrum) by GC-MS. Proc. International Seminar on Natural Products Chemystry and Utilization of Natural Resources. Page 501-303. Jakarta: UI-INESCO.

Kartika, B., Hastuti, D., dan Supratno, W., 1988. Pedoman Uji Inderawi Bahan Pangan. Yogyakarta: PAU Pangan dan Gizi Universitas GadjahMada.

Kosasih, E.N., Tony S., dan Hendro, H., 2006. Peran Antioksidan pada Lanjut Usia. Jakarta: Pusat Kajian Nasional Masalah Lanjut Usia. 
Lumbangaol, M.A., Nainggolan, R J dan Yusraini, E.,2016.Pengaruh Perbandingan Sari Nenas dengan Sari Daun Katuk dan Konsentrasi Karagenan terhadap Mutu permen Jelly. Jurnal Rekayasa Pangan dan Pertanian.4(4): 492-499. Medan: Universitas Sumatera Utara Medan.

Maitimu, C.V., Legowo, A.M., Al-Baari, 2012. Parameter Keasaman Susu Pasteurisasi dengan Penambahan Ekstrak Daun Aileru (Wrightia caligria).J. Aplikasi Teknologi Pangan. 1(1): 7-11.

Malangngi, L.P., Sangi, M.S., dan Paendong, J.J.E., 2012. Penentuan Kandungan Tanin dan Uji Aktivitas Ekstrak Biji Buah Alpukat (Persea Americana Mill).J. MIPA Unsrat Online.1(1):5-10.

Mangan, Y., 2009. Solusi Sehat Mencegah dan Mengatasi Kanker. Jakarta (ID): Agromedia Pustaka.

Pomeranz,Y., dan Meloan, C.E., 1980. Food Analysis: Theory and Practice Second Edition. New York: Van Nostrand Reinhold Company.

Rehman, R., Akram, M., Akhtar, N., Jabeen, Q., Saeed, T., Shah, S.M.A., Ahmed, K., Shaheen, G., dan Asif, H.M., 2011.Zingiber officinale Roscoe (Pharmacological Activity).Journal of Medicinal Plants Research. 5: 344-348.

Santoso, U., Fenita, Y., dan Kususiah, 2008. Penggunaan Ekstrak Air Daun Katuk sebagai Pengganti Feed Additive Komersial Untuk Memproduksi Meat Designers yang Efisien.Laporan Riset
Unggulan Universitas. Bengkulu: Universitas Bengkulu.

Sarastani, D., Suwarna, T.S., Tien, R.M., Dedi, F., dan Anton, A., 2002.Aktivitas AntioksidanEkstrak dan Fraksi Ekstrak Biji Atung.Jurnal Teknologi dan Industri Pangan13(2): 149-156.

Strycharz, S., Shetty, K., 2002. Effect of Agrobacterium Rhizongenes on Phenolic Content of Mentha Pulegium Elite Clonal Line Phytoremediation.Process Biochemistry.38(2): 287-293.

Sudarmadji, S., Haryono, B., dan Suhardi, 1984. Prosedur Analisis Kadar Serat dan untuk Bahan Makanan Pertanian.Yogyakarta: Liberty.

Supiyanti, W., Wulansari, E.D., dan Kusmita, L., 2010.Uji Aktivitas Antioksidan dan Penentuan Kandungan Antosianin Total Kulit buah Manggis (Garciniamangostana L).Majalah Obat Tradisional 5(2): 64-70. Winarno, F.G., 2004. Kimia Pangan dan Gizi. Jakarta: PT Gramedia Pustaka Utama. Yazakka, I.M., dan Susanto, W.H., 2015. Karakteristik Hard Candy Jahe Berbasis Nira Kelapa (Kajian Jenis Jahe dan Konsentrasi sari Jahe). Jurnal Pangan dan Agroindustri3(3): 1214-1223. Malang: FTP Universitas Brawijaya.

Yen, G.O. and Chen, Y., 1995. Antioxidant Activity of Various Tea Extracts in Relation to Their Antimutagenicity. Journal of Agricultural and Food Chemistry. giorgiomangan43(1): 27-32. 